\title{
KAPABILITAS DYNAMIC GOVERNANCE DALAM OPTIMALISASI PENGELOLAAN LAHAN TERBUKA HIJAU DI KOTA MAKASSAR
}

\author{
Muchlas M. Tahir \\ Zulfan Nahruddin \\ Universitas Muhammadiah Makassar \\ email: muchlasmtahir7@gmail.com
}

\begin{abstract}
This study aims to determine the development of Dynamic Governance Capabilities in optimizing the management of green open land in the city Makassar.Metode This study used a qualitative approach through the instrument interview, observation and documentation. The process of data analysis including data collection, data reduction, data presentation, and conclusion. The results showed the vertical system in the optimization of green open land needs to be supported by the active participation of the community by contributing as much as $10 \%$ of their land to green open land in addition to the boost in the form of pemerdayaan green community as a form of community participation in the optimization of open land needs to be strengthened by the municipality at the same time show the need to demonstrate the utilization of spaces awakened by way of planting on the roofs and walls of buildings in addition to the strategy in terms of policies can be reached by encouraging the preparation and adoption of Local Regulations related to the RTH is part of our capability Dynamic Governance includes thinking ahead (thinking ahead), thinking again (thinking again), and cross-border thinking (thinking across), which focuses on optimizing the management of green space produces a series of adjustments to the program as program Lorong garden (Loose) which can contribute to the optimization of green space in the city of Makassar.
\end{abstract}

Keywords: capability, Dynamic, Governance, $R T H$

\section{PENDAHULUAN}

Negara dengan birokrasi pemerintahan dituntut untuk merubah pola pelayanan diri birokratis elitis menjadi birokrasi populis. Dimana sektor swasta sebagai pengelola sumber daya di luar negara dan birokrasi pemerintah pun harus memberikan konstribusi dalam usaha pengelolaan sumber daya yang ada. Penerapan cita good governance pada akhirnya mensyaratkan keterlibatan organisasi masyarakatan sebagai kekuatan penyeimbang Negara.

Dalam konsep governance, pemerintah hanya menjadi salah satu actor dan tidak selalu menjadi aktor yang menentukan. Implikasi peran pemerintah sebagai pembangunan maupun penyedia jasa layanan dan infrastruktur akan bergeser menjadi bahan pendorong terciptanya lingkungan yang mampu memfasilitasi pihak lain di komunitas. Governance menuntut redefinisi peran negara, dan itu berarti adanya redefinisi pada peran warga. Adanya tuntutan yang lebih besar pada warga, antara lain untuk memonitor akuntabilitas pemerintahan itu sendiri. (Hetifa, 2003) 
Penilaian penerapan good governance di Indonesia, berbagai assessment yang diadakan oleh lembaga-lembaga internasional selama ini menyimpulkan bahwa Indonesia sampai saat ini belum pernah mampu mengembangkan good governance. Mungkin karena gerakan reformasi yang digulirkan masih terbatas pada praktik KKN (Clean Governance). Sofian Effendi (Surjadi, 2012:22) menyatakan bahwa kebijakan yang tidak jelas, penempatan personal yang tidak kredibel, serta kehidupan politik yang kurang berorientasi pada kepentingan bangsa yang telah menyebabkan dunia bertanya apakah Indonesia memang serius melaksanakan good governance.

Tuntutan masyarakat kepada pemerintah dalam kaitan penyelenggaraan pemerintahan yang baik terus gencar dilaksanakan seiring meningkatnya tingkat pengetahuan dan kepedulian masyarakat terhadap penyelenggaraan pemerintahan. Masyarakat senantiasa menginginkan reformasi atau perubahan pada pelayanan public dan peyelenggaran pemerintahan yang baik mengingat selama ini dalam pelaksanaanya masih dianggap kurang baik.

Jika melihat kondisi kota Makassar sekarang ini dengan slogan Makassar Menuju Kota Dunia, banyak tantangan yang kemudian akan dihadapi oleh pemerintah dan masyarakat kota Makassar terkait dengan pembangunan infrastruktur dan pembangunan lainnya. Melihat hal tersebut pemerintah banyak melakukan pembangunan mulai dari pembangunan fisik maupun nonfisik.

$$
\text { Salah satu tuntutan }
$$
masyarakat pada pemerintah dalam kaitannya penyelenggaraan pemerintahan dibidang tata kota yakni perlunya pembangunan yang tertata dengan baik memperhatikan kepentingan masyarakat akan lingkungan yang kondusif.

Upaya inovatif pembangunan dan perkembangan kota dewasa ini yang semakin pesat yang membawa konsekuensi makin meningkatnya kebutuhan lahan untuk mengakomodasi pembangunan dan perkembangan kota tersebut Lahanlahan kosong potensial yang selama ini cukup tersedia menjadi semakin menurun. Ruang terbuka hijau sebenarnya juga merupakan kebutuhan yang tidak dapat diabaikan, seperti juga halnya fasilitas sosial lainnya, seperti peribadatan, pendidikan, kesehatan, dan sebagainya. Ruang terbuka hijau juga termasuk salah satu elemen kota dan kehadirannya dalam suatu kota didasarkan pada ketentuan dan standar-standar tertentu (Rijal, 2008).

Zoeraini (dalam Kusuma, 2013) mengemukakan ruang terbuka hijau merupakan salah satu elemen penting dalam suatu kota. Ruang terbuka hijau berfungsi untuk menyeimbangkan keadaan ekologi pada suatu kawasan agar terjadi keseimbangan antara ekosistem dan perkembangan pembangunan di era modern. Fungsi dari keberadaan ruang terbuka hijau antara lain adalah sebagai penyeimbang ekosistem ekologis, yaitu dimana ruang terbuka hijau tersebut menjadi tempat tinggal para binatang liar seperti burung. Sebagai fungsi arsitektural yaitu menambah keindahan dimana ruang terbuka hijau juga memberikan rasa yang berbeda melalui penataan bentuk warna dan jenis vegetasi ruang 
terbuka hijau, sebagai fungsi sosial yaitu tempat berinteraksi masyarakat sekitar dimana ruang terbuka hijau tersebut memberikan kesejukan, kenyamanan sehingga masyarakat terwadahi dalam melakukan interaksi berbagai kegiatan, sebagai .pencegah bencana seperti erosi tanah yang di timbulkan baik dari udara maupun pengikisan air, akar tanaman berfungsi untuk mengikat tanah agar kuat dari serangan air

Sementara itu, pesatnya pembangunan di kota Makassar memang berdampak negatif terhadap lingkungan yang ada. BLHD sendiri menurutnya berperan dalam melakukan pengawasan terhadap pencemaran lingkungan. Masalah lingkungan merupakan masalah yang sangat kompleks, sehingga BLHD dalam hal ini berperan terus melakukan koordinasi dengan seluruh SKPD terkait pentingnya pemeliharaan lingkungan. Selain tingkat pengawasan pencemaran lingkungan, BLHD juga berkaitan dengan pengawasan Amdal. Amdal memegang peranan yang sangat penting dalam pengambilan keputusan pejabat yang berwenang dalam rangka memastikan bahwa pembangunan yang dilaksanakan dapat menjamin kelestarian dan keberlangsungan lingkungan hidup. Hampir semua bangunan-bangunan baru di Kota Makassar telah mengabaikan aspek lingkungan diantaranya tak mengadakan ruang terbuka hijau yang memadai, serta di Makassar sendiri banyak lahan yang sejatinya bisa dijadikan taman hijau namun dengan perkembangan kota yang begitu pesat berubah menjadi bangunan ruko serta bangunan hotel yang sudah merambah ke pemukiman warga.

Pendekatan governance membutuhkan dynamic governance sebagai bentuk lain pengembangan dalam pemahaman ilmu pemerintahan dan pendekatan administrasi publik modern hal ini membantu melihat permasalahan secara menyeluruh (holistic) salah satunya adalah model pembangunan dynamic governance di Singapura oleh Neo dan Chen. dynamic governance terlaksana jika ada pembelajaran terus menerus untuk menghasilkan dan mengeksekusi kebijakan adaptif (adaptive policy) melalui pengembangan dynamic capabilities (mencakup kemampuan thinking ahead, thinking again dan thinking across) pada proses pembangunan able people dan agile process. (Anwar, 2009). Penelitian ini dibatasi pada dynamic capabilities sebagai bagian dynamic governance untuk memperoleh gambaran secara mendalam mengenai kemampuan thinking ahead, thinking again dan thinking across dalam pengelolaan lahan terbuka hijau kota Makassar. Secara spesifik penelitian ini bertujuan untuk mengetahui pengembangan Kapabilitas Dynamic Governance dalam optimalisasi pengelolaan lahan terbuka hijau di Kota Makassar.

\section{TINJAUAN PUSTAKA}

\section{Konsep Good Governance}

Menurut World Bank, Good

Governance ialah suatu penyelenggaraan manajemen pembangunan yang solid dan bertanggung jawab yang sejalan dengan prinsip demokrasi dan pasar yang efisien, penghindaran terhadap 
kemungkinan salah satu alokasi atau investasi, dan pencegahan korupsi baik yang secara politik maupun administrative, menjalankan disiplin anggaran serta penciptaan legal dan political framework bagi tumbuhnya aktivitas usaha. Sedangkan menurut UNDP Good Governance menunjukkan suatu proses yang memposisikan rakyat dapat mengatur ekonominya, institusi dan sumbersumber sosial dan politiknya tidak hanya sekedar dipergunakan untuk pembangunan, tetapi juga untuk menciptakan kohesi, integritas serta untuk kesejahteraan rakyatnya (Teguh, 2011: 22)

Dinamika perjalanan praktek pemerintahan yang senantiasa berhadapan dengan lingkungan dan harapan masyarakat yang juga menjadi pendorong berubahnya paradigma pemerintahan secara konseptual. Tuntutan terhadap perbaikan kinerja pemerintah membuat pemerintah mencari praktek yang tepat yang dapat memenuhi harapan masyarakat. Hal ini juga kemudian secara akademik melahirkan kajian-kajian tentang konsepsi implementasi pemerintahan yang dapat memenuhi harapan masyarakat dan tuntutan lingkungan strategis tersebut. Konsep yang paling aktual dalam konteks ini adalah konsep good governance.

Dari uraian tersebut, maka unsur utama yang dilibatkan dalam penyelenggaraan kepemerintahan menurut UNDP terdiri atas tiga macam, yaitu the state (negara/pemerintah), the private sector (swasta), dan civil society organization (organisasi masyarakat). Hubungan di antara ketiga unsur utama dalam penyelenggaraan governance tentunya saling mempengaruhi, saling membutuhkan, atau bahkan saling ketergantungan dalam upaya mewujudkan kepemerintahan yang baik (Widodo, 2008:110)

\section{Prinsip-Prinsip Governance}

Good

Good Governance awalnya digunakan dalam dunia usaha (corporate) dan adanya desakan untuk menyusun sebuah konsep dalam menciptakan pengendalian yang melekat pada korporasi dan manajemen professionalnya, maka ditetapkan Good Corporate Governance. Sehingga dikenal prinsip-prinsip utama dalam Governance Corporate adalah: transparansi, akuntabilitas, fairness, responsibilitas, dan responsivitas. Prinsip-prinsip Good Governance diatas cenderung kepada dunia usaha, sedangkan bagi suatu organisasi publik bahkan dalam skala Negara prinsip-prinsip tersebut lebih luas menurut Universitas Sumatera Utara UNDP melalui LAN) menyebutkan bahwa adanya hubungan sinergis konstruktif di antara Negara, sektor swasta atau privat dan masyarakat yang disusun dalam sembilan pokok karakteristik Good Governance, yaitu: Dari berbagai hasil yang dikaji Lembaga Administrasi Negara (LAN) telah menyimpulkan sembilan aspek fundamental dalam perwujudan clean and good governance, (Dalam Pohan, 2014) : partisipasi (participation), penegakan hukum (rule of law), tranparansi (tranparency), responsive (responsiveness), orientasi kesepakatan (consensus orientation), keadilan (equity), efektifitas (effectiveness) dan efesiensi 
(efficiency), akuntabilitas (accountability), dan visi strategi (strategic vision).

\section{Fungsi Ruang terbuka Hijau}

Ruang Terbuka dapat berupa ruang terbuka yang diperkeras maupun ruang terbuka biru (RTB) yang berupa permukaan sungai, danau maupun areal-areal yang diperuntukkan sebagai kawasan genangan. Ruang terbuka adalah ruang yang bisa diakses oleh masyarakat baik secara langsung dalam kurun waktu terbatas maupun secara tidak langsung dalam kurun waktu tidak tertentu. Ruang terbuka berfungsi sebagai ventilasi kota, dapat berupa jalan, trotoar, ruang terbuka hijau, dan sebagainya. Ruang terbuka juga dapat diartikan sebagai ruang interaksi seperti kebun binatang, taman rekreasi. Dilihat dari sifatnya, ruang terbuka dapat dibedakan menjadi : (1) Ruang terbuka privat, memiliki batas waktu tertentu untuk mengaksesnya dan kepemilikannya bersifat pribadi seperti, halaman rumah tinggal (2). Ruang terbuka semi privat, kepemilikannya pribadi tetapi dapat diakses langsung oleh masyarakat seperti, Senayan, Ancol. (3). Ruang terbuka umum, kepemilikannya oleh pemerintah dan bisa diakses langsung oleh masyarakat tanpa batas waktu.

Ruang Terbuka Hijau (RTH) (dalam Direktorat PU, 2006) sebagai infrastruktur hijau perkotaan adalah bagian dari ruang-ruang terbuka (open spaces) suatu wilayah perkotaan yang diisi oleh tumbuhan, tanaman, dan vegetasi (endemik, introduksi) guna mendukung manfaat langsung dan/atau tidak langsung yang dihasilkan oleh RTH dalam kota tersebut yaitu keamanan, kenyamanan, kesejahteraan, dan keindahan wilayah perkotaan tersebut. Sedangkan secara fisik RTH dapat dibedakan menjadi RTH alami yang berupa habitat liar alami, kawasan lindung dan taman-taman nasional, maupun RTH non-alami atau binaan yang seperti taman, lapangan olah raga dan kebun bunga.

Melalui Peraturan Menteri Dalam Negeri Nomor 1 Tahun 2007 Tentang Penataan Ruang Terbuka Hijau Kawasan Perkotaan pada bab 1 pasal 1 ayat 2 yang menyatakan bahwa Ruang Terbuka Hijau Kawasan Perkotaan yang selanjutnya disingkat RTHKP adalah bagian dari ruang terbuka suatu kawasan perkotaan yang diisi oleh tumbuhan dan tanaman guna mendukung manfaat ekologi, sosial, budaya, ekonomi dan estetika. Kawasan Perkotaan adalah kawasan yang mempunyai kegiatan utama bukan pertanian dengan susunan fungsi kawasan sebagai tempat permukiman perkotaan, pemusatan dan distribusi pelayanan jasa pemerintahan, pelayanan sosial dan kegiatan ekonomi.

\section{Kapabilitas \\ Governance}

Komponen capabilitas mencerminkan bagaimana pola pikir orang singapura atas dasar tiga hal yaitu thinking ahead, thinking again dan thinking across. Thinking ahead menunjukkan kapasitas berpikir dalam merumuskan kondisi dimasa mendatang yang mungkin dapat berdampak pada kondisi dalam negeri. Sebaliknya, thinking again akan merefleksikan kemampuan dan keterbukaan untuk berkaca pada 
kebijakan sebelumnya, kemudian dievaluasi dan disempurnakan untuk memaksimalisasi pencapaian tujuan. Sementara, thinking across merupakan kemampuan dan keterbukaan wawasan dalam mempelajari pengalaman ide dan konsep actor-aktor lain. (Kazim, dkk, 2015). Untuk lebih jelasnya mengenai berfikir ke depan (thinking ahead), berpikir lagi (thinking again), dan berpikir lintas batas (thinking across) diuraikan (dalam Aminullah, 2014).

\section{METODE PENELITIAN}

\section{Lokasi dan Rancangan}

\section{Penelitian}

Penelitian ini berlokasi pada Kantor Badan Lingkungan Hidup Daerah Kota Makassar, dengan pertimbangan perlu melakukan penelitian untuk mengetahui capabilities dynamic governance dalam optimalisasi pengelolaan lahan terbuka hijau Kota Makassar. Penelitian ini menggunakan pendekatan kualitatif dengan alasan bahwa temuan-temuan dalam penelitian kualitatif tidak diperoleh melalui prosedur statistik atau bentuk hitungan lainnya serta tipe penelitian deskriptif digunakan untuk mengambarkan secara terperinci mengenai keadaan atau peristiwa yang dideskripsikan secara nyata terkait obyek yang diteliti. Dalam pengertiannya, penelitian kualitatif yakni penelitian yang bermaksud untuk memahami fenomena tentang apa yang dialami oleh subyek penelitian, misalnya perilaku, persepsi, motivasi, tindakan, dll., secara holistik (utuh) dan dengan cara deskripsi dalam bentuk kata-kata dan bahasa pada suatu konteks khusus yang alamiah dengan memanfaatkan berbagai metode alamiah. (Moleong, 2012:6).

\section{Informan Penelitian}

Untuk memudahkan penentuan informan di lapangan, peneliti menargetkan informan kuncinya adalah pegawai pada kantor Badan Lingkungan Hidup Daerah Kota Makassar, dan bagian-bagian penting dalam kantor tersebut yang dapat memberikan informasi yang dibutuhkan oleh peneliti termasuk masyarakat sebagai penerima dampak dari kebijakan.

\section{Teknik Pengumpulan Data}

Teknik pengumpulan data yang dipergunakan dalam penelitian ini yaitu observasi dengan melakukan pengamatan langsung dilapangan sesuai dengan obyek yang diteliti. Kuesioner yang dibagikan kepada responden, wawancara langsung kepada informan dengan menggunakan pedoman wawancara. Dokumentasi dengan kajian literatur/kepustakaan, dokumen, dan sumber tertulis lainnya yang memiliki kaitan dengan kebutuhan data dan informasi pada penelitian ini.

\section{Analisis Data}

Analisis data mengacu pada langkah-langkah yang dipakai oleh Miles dan Huberman (2007:16-19) yang terdiri dari tiga alur kegiatan secara bersamaan, meliputi: pengumpulan data; reduksi data; display dan penarikan kesimpulan/verifikasi. Untuk meningkatkan kemampuan peneliti dalam menilai keakuratan hasil penelitian serta meyakinkan pembaca tentang akurasi penelitian yang 
dilakukan, maka harus menggunakan beragam strategi dalam melakukan validasi (Creswell, 2010:286). Selanjutnya Sugiyono (2011:333) mengemukakan bahwa analisis data proses mencari dan menyusun secara sistematis data yang diperoleh dari wawancara, catatan lapangan dan dokumentasi, dengan cara mengorganisasikan data ke dalam kategori, menjabarkan ke dalam unitunit, melakukan sintesa, menyusun ke dalam pola, memilih mana yang penting dan yang akan dipelajari, dan membuat kesimpulan sehingga mudah dipahami oleh diri sendiri maupun orang lain.

\section{HASIL PENELITIAN}

Untuk mengetahui pengembangan Kapabilitas Dynamic Governance dalam optimalisasi pengelolaan lahan terbuka hijau di Kota Makassar melalui aspek berikut ini :

\section{Berfikir ke depan (thinking ahead)}

Berdasarkan hasil wawancara dapat diketahui bahwa langkah antisipasi yang dilakukan pemerintah yaitu dalam bentuk sosialisasi terhadap pencemaran lingkungan yang mengedepankan Pentingnya pengawasan dan pengendalian terhadap pencemaran lingkungan hidup membutuhkan perpaduan dengan seluruh stakeholder dan masyarakat untuk bekerjasama dalam mengelola lingkungan. Salah satu bentuk pencemaran lingkungan diakibatkan oleh limbah (Bahan berbahaya dan beracun). Khusus untuk kebijakan pada Lahan Terbuka Hijau menelisik pada kebijakan Kepmendagri No. 01/2007, tentang penyediaan pemanfaatan ruang terbuka hijau wilayah kota (RTHKP).

Berdasarkan hasil wawancara dapat diketahui bahwa kebijakan pemanfaatan lahan terbuka hijau wilayah kota (RTHKP) mengharuskan setiap kota memiliki lahan terbuka hijau seperti taman perkotaan dan hutan kota minimal 30 persen. Namun hal ini belum dapat terpenuhi oleh kota manapun di Indonesia termasuk Makassar. Selain itu implementasi Undang-Undang Nomor 26 Tahun 2007 tentang Penataan Ruang, merupakan bentuk antisipasi pemerintah dengan tujuan merumuskan Pedoman Penyediaan dan Pemanfaatan Ruang Terbuka Hijau di Kawasan Perkotaan yang menjadi acuan dalam berbagai kebijakan dan kegiatan pengelolaan ruang terutama pengelolaan ruang terbuka termasuk ruang publik di Kota Makassar.

Berdasarkan hasil wawancara dapat dipahami bahwa pemahaman pencapaian tujuan belum dapat dikatakan dapat dipahami secara menyelurh karena masih terbendung oleh arus urbanisasi perkembangan perkotaan seperti pembangunan perumahan dan ruko-ruko belum lagi konvensi wilayah resapan air banyak terjadi yang disebabkan oleh sejumlah pembangunan. Selain itu pemenuhan RTH sejumlah 30 Persen yang disyarakat dalam UndangUndang Nomor 26 Tahun 2007 masih belum dapat terpenuhi.

Berdasarkan hasil wawancara dapat diketahui bahwa opsi starategi yang dapat dimunculkan yaitu pemanfaatan ruang-ruang terbangun dengan cara melakukan penanaman pada atap dan tembok bangunan selain itu strategi dari segi kebijakan 
dapat ditempuh dengan mendorong penyusunan dan penetapan Peraturan Daerah terkait dengan RTH dan Rencana Induk RTH agar perencanaan pembangunan RTH memiliki kekuatan hukum melalui peran DPRD.

\section{Berpikir Lagi (Thinking Again)}

Berdasarkan hasil wawancara dapat diketahui bahwa hasil tinjuan yang dilakukan pemerintah kota masih kesulitan dalam memenuhi target RTH dimana kota Makassar masih dibawah $10 \%$ dari $30 \%$ persyaratan yang ada dalam UndangUndang Nomor 26 Tahun 2007 Tentang Penataan Ruang. Peninjuan dilakukan dengan memaksimal pendataan dan mengapdate kembali ruang terbuka hijau yang ada di Kota Makassar yang mengunakan teknologi dari satelit selain itu juga mendapat klarifikasi langsung dari kelurahan mengenai area lingkungan terbuka hijau yang ada di Kota Makassar. Berdasarkan hasil wawancara dapat diketahui bahwa mendesain ulang kebijakan dan program RTH dapat dilakukan pemerintah secara sinergis dengan tidak terlepas dari strategi pengelolaan lingkungan hidup terpadu lainnya yang difokuskan pada empat aspek pengelolaan, yaitu permasalahan sampah, RTH, kualitas air, dan fasilitas umum lain yang terkait erat.

Berdasarkan hasil wawancara dapat diketahui bahwa system baru yang dapat dilakukan di Kota Makassar dengan mengadakan strategi vertical garden yang dapat meningkatkan fungsi RTH namun tidak menambah luasan RTH namun strategi baru yang perlu dipotimalkan adalah menyediakan lahan terbuka hijau pada lahan masyarakat yakni sejumlah $10 \%$. Selain mendukung system Vertikal tersebut juga perlu difollow up dengan peneningkatan partisipasi masyarakat dalam mendukung kebijakan lahan terbuka hijau. Berdasarkan hasil wawancara dapat diketahui bahwa system vertical dalam optimalisasi lahan terbuka hijau perlu didukung oleh partisipasi aktif masyarakat dengan mengkontribusikan sebanyak 10\% lahan mereka untuk lahan terbuka hijau disamping itu dorongan berupa pemerdayaan komunitas hijau sebagai bentuk partisipasi masyarakat dalam optimalisasi lahan terbuka perlu diperkuat oleh pemerintah kota.

\section{Berpikir lintas batas (thinking across)}

Berdasarkan hasil wawancara dapat diketahui bahwa indikator adopsi dapat dilakukan dengan mengikuti pola yang digambarkan oleh Negara lain seperti di Amerika dan Jepang dimana RTH dibangun melalui ijin sebagai bagian karya pembangunan dalam artian ada aturan pembatasan perencanaan kota, istilahnya sub-division control yakni Metode menyisihkan lahan untuk RTH didasarkan pada kriteria dengan skala dan tipe karya pembangunan tertentu sesuai yang dikehendaki, sekaligus merupakan kondisi penting agar usulan pembangunan disetujui hal ini berlaku di Amerika dan di Jepang juga sangat mempertimbangkan struktur bangunan di dalamnya yang memerlukan proyeksi sebuah area kosong dan terbuka untuk umum merupakan contoh yang patut untuk ditiru atau di adopsi. 
Berdasarkan hasil wawancara dapat diketahui bahwa evaluasi yang perlu diperkuat adalah komitmen bersama untuk menambah luas lahan agar mencapai $30 \%$ luas lahan terbuka hijau kota selain itu perlunya peningkatan peran pemerintah, swasta dan masyarakat yang sinergis untuk mengoptimal Lahan Terbuka Hijau Kota Makassar. Berdasarkan hasil wawancara dapat diketahui bahwa indikator penyesuaian menunjukkan perlunya sosialisasi pada publik megenai pentingnya menjaga keseimbangan dan keberlangsungan lingkungan kota melakukan inventarisasi wilayahwilayah yang termasuk sebagai Ruang Terbuka Hijau serta melakukan penegakan hukum disamping itu penyesuaian juga perlu mempertimbangkan sinergitas antara pemerintah dan masyarakat melalui serangkaian program seperti program Lorong garden (Longgar) yang sekiranya dapat memberikan kontribusi pada optimalisasi RTH Kota Makassar.

\section{PEMBAHASAN}

Penelitian ini menunjukkan ketiga komponen atau variabel Kapabilitas Dynamic Governance Dalam Optimalisasi Pengelolaan Lahan Terbuka Hijau Di Kota Makassar yaitu berfikir ke depan (thinking ahead), berpikir lagi (thinking again), dan berpikir lintas batas (thinking across) (Aminullah, 2014) diperoleh gambaran bahwa kemampuan mengantisipasi merupakan bagian dari komponen berfikir ke depan terlihat dari kebijakan pemanfaatan lahan terbuka hijau wilayah kota (RTHKP) mengharuskan setiap kota memiliki lahan terbuka hijau seperti taman perkotaan dan hutan kota minimal 30 persen namun hal ini belum dapat terpenuhi di Kota Makassar selain itu indikator pemahaman pencapaian tujuan belum dapat dikatakan dapat dipahami secara menyelurh karena masih terbendung oleh arus urbanisasi perkembangan perkotaan seperti pembangunan perumahan dan ruko-ruko selain itu opsi startegi yang dapat dimunculkan dalam penelitian ini yaitu pemanfaatan ruang-ruang terbangun dengan cara melakukan penanaman pada atap dan tembok bangunan selain itu strategi dari segi kebijakan dapat ditempuh dengan mendorong penyusunan dan penetapan Peraturan Daerah terkait dengan RTH dan Rencana Induk RTH agar perencanaan pembangunan RTH memiliki kekuatan hukum melalui peran DPRD.

Pada variabel berpikir lagi (thinking again) memberikan gambaran bahwa adanya hasil tinjuan yang dilakukan pemerintah kota masih kesulitan dalam memenuhi target RTH dimana kota Makassar masih dibawah $10 \%$ dari $30 \%$ persyaratan yang ada dalam UndangUndang Nomor 26 Tahun 2007 Tentang Penataan Ruang. Peninjuan dilakukan dengan memaksimal pendataan dan mengapdate kembali ruang terbuka hijau yang ada di Kota Makassar yang mengunakan teknologi dari satelit selain itu juga mendapat klarifikasi langsung dari kelurahan mengenai area lingkungan terbuka hijau yang ada di Kota Makassar. Kemudian indikator mendesain ulang kebijakan dan program RTH dapat dilakukan pemerintah secara sinergis dengan tidak terlepas dari strategi 
pengelolaan lingkungan hidup terpadu lainnya yang difokuskan pada empat aspek pengelolaan, yaitu permasalahan sampah, RTH, kualitas air, dan fasilitas umum lain yang terkait erat. Berdasarkan Peraturan Daerah Kota Makassar Nomor 6 Tahun 2006 tentang Rencana Tata Ruang Wilayah Kota Makassar Tahun 2005-2015, persentase luas Ruang Terbuka Hijau ditargetkan 5\% dari kawasan pusat kota. Pemanfaatan Ruang Terbuka Hijau sebagai ruang public diharapkan dapat berfungsi secara ekologis,sosial/budaya arsitektural ekonomi yang meningkatkan kualitas air tanah,mencegah banjir mengurangi polusi udara dan menurunkan temperature kota dan menjadikan keteduhan pada Ruang Terbuka Hijau sebagai ruang public. (Maruddani, dkk 2010)

Selanjuntnya indikator menjalankan system baru sebagai bagian terakhir dari variabel berpikir lagi (thinking again) menjelaskan adanya vertical system dalam optimalisasi lahan terbuka hijau perlu didukung oleh partisipasi aktif masyarakat dengan mengkontribusikan sebanyak $10 \%$ lahan mereka untuk lahan terbuka hijau disamping itu dorongan berupa pemerdayaan komunitas hijau sebagai bentuk partisipasi masyarakat dalam optimalisasi lahan terbuka perlu diperkuat oleh pemerintah kota.

Pada variabel berpikir lintas batas (thinking across) diperoleh gambaran yaitu indikator adopsi dapat dilakukan dengan mengikuti pola yang digambarkan oleh Negara lain seperti di Amerika dan Jepang dimana RTH dibangun melalui ijin sebagai bagian karya pembangunan dalam artian ada aturan pembatasan perencanaan kota, istilahnya subdivision control yakni Metode menyisihkan lahan untuk RTH didasarkan pada kriteria dengan skala dan tipe karya pembangunan tertentu sesuai yang dikehendaki, sekaligus merupakan kondisi penting agar usulan pembangunan disetujui hal ini berlaku di Amerika dan di Jepang juga sangat mempertimbangkan struktur bangunan di dalamnya yang memerlukan proyeksi sebuah area kosong dan terbuka untuk umum merupakan contoh yang patut untuk ditiru atau di adopsi. Selanjutnya indikator evaluasi yang perlu diperkuat adalah komitmen bersama untuk menambah luas lahan agar mencapai $30 \%$ luas lahan terbuka hijau kota selain itu perlunya peningkatan peran pemerintah, swasta dan masyarakat yang sinergis untuk mengoptimal Lahan Terbuka Hijau Kota Makassar. Hal sesuai dengan konsep governance lebih merupakan serangkaian proses interaksi sosial politik antara pemerintahan dengan masyarakat dalam berbagai bidang yang berkaitan dengan kepentingan masyarakat dan intervensi pemerintah atas kepentingan-kepentingan tersebut (Sedarmayanti, 2009: 273).

Selanjutnya indikator penyesuaian yang merupakan bagian dari variabel berpikir lintas batas (thinking across) menunjukkan perlunya sosialisasi pada publik megenai pentingnya menjaga keseimbangan dan keberlangsungan lingkungan kota melakukan inventarisasi wilayah-wilayah yang termasuk sebagai Ruang Terbuka Hijau serta melakukan penegakan hukum disamping itu penyesuaian 
juga perlu mempertimbangkan sinergitas antara pemerintah dan masyarakat melalui serangkaian program seperti program Lorong garden (Longgar) yang sekiranya dapat memberikan kontribusi pada optimalisasi Ruang Terbuka Hijau yang ada di Kota Makassar. Komponen capabilitas mencerminkan bagaimana pola pikir atas dasar tiga hal yaitu thinking ahead, thinking again dan thinking across. Thinking ahead menunjukkan kapasitas berpikir dalam merumuskan kondisi dimasa mendatang yang mungkin dapat berdampak pada kondisi dalam negeri. Sebaliknya, thinking again akan merefleksikan kemampuan dan keterbukaan untuk berkaca pada kebijakan sebelumnya, kemudian dievaluasi dan disempurnakan untuk memaksimalisasi pencapaian tujuan. Sementara, thinking across merupakan kemampuan dan keterbukaan wawasan dalam mempelajari pengalaman ide dan konsep actor-aktor lain. (Kazim, dkk, 2015).

Pada akhirnya penelitian ini menjelaskan adanya vertical system dalam optimalisasi lahan terbuka hijau perlu didukung oleh partisipasi aktif masyarakat dengan mengkontribusikan sebanyak $10 \%$ lahan mereka untuk lahan terbuka hijau disamping itu dorongan berupa pemerdayaan komunitas hijau sebagai bentuk partisipasi masyarakat dalam optimalisasi lahan terbuka perlu diperkuat oleh pemerintah kota sekaligus memperlihatkan perlunya memperlihatkan pemanfaatan ruangruang terbangun dengan cara melakukan penanaman pada atap dan tembok bangunan selain itu strategi dari segi kebijakan dapat ditempuh dengan mendorong penyusunan dan penetapan Peraturan Daerah terkait dengan RTH.

\section{KESIMPULAN DAN SARAN}

Kapabilitas Dynamic

Governance yang ditunjukkan dalam penelitian ini mengungkapkan bahwa adanya antisipasi RTH melalui kebijakan, pemahaman pencapaian tujuan belum dapat dikatakan dapat dipahami secara menyeluruh namun opsi startegi yang dapat dimunculkan dalam penelitian ini yaitu pemanfaatan ruang-ruang terbangun dengan cara melakukan penanaman pada atap dan tembok bangunan selain itu strategi dari segi kebijakan dapat ditempuh dengan mendorong penyusunan dan penetapan Peraturan Daerah terkait dengan RTH. Selanjutnya peninjauan kebijakan dapat dilakukan dengan memaksimal pendataan dan mengapdate kembali ruang terbuka hijau yang ada di Kota Makassar selain itu desain kebijakan tidak terlepas dari strategi pengelolaan lingkungan hidup secara terpadu termasuk didalamnya vertical system yang perlu didukung oleh partisipasi aktif masyarakat serta sinergitas antara pemerintah dan masyarakat melalui serangkaian program seperti program Lorong garden (Longgar) yang memberikan kontribusi pada optimalisasi Ruang Terbuka Hijau yang ada di Kota Makassar. Program pemerintah kota Makassar seperti lorong garden perlu mendapat dukungan semua pihak terutama masyarakat agar berpartisipasi secara aktif dalam memaksimal setiap ruang yang ada dilahannya masing-masing agar membantu mengoptimalkan ruang/lahan terbuka hijau di Kota 
Makassar agar sekiranya mampu memaksimal pemenuhan persentasi RTH sesuai kebijakan pemerintah.

\section{DAFTAR PUSTAKA}

Aminullah. 2014. Dynamic Governance (Kerangka Konseptual Melembagakan Budaya, Kapabilitas, dan Perubahan). Jurnal Kebangsaan Volume 9 Nomor 1 Maret 2014. Fakultas Ilmu Sosial dan Ilmu Politik Universitas Yudharta Pasuruan.

Anwar, Rozan. 2009. Pengembangan Model tentang Pengaruh Able People dan Agile Process terhadap Dynamic Capabilities dalam Proses Kebijakan Publik (Studi Kasus Pelayanan Bidang Pendidikan di Kabupaten Jembrana, Propinsi Bali). (Disertasi) Fisip Ilmu Administrasi. Depok : Universitas Indonesia

Creswell, W.J. 2010. Reseach Design Qualitative and Quantitative Approach. Penerjemah Achmad Fawaid. Yogyakarta: Pustaka Pelajar.

Hetifa, Sumarto Sj. 2003. Inovasi, Partisipasi dan Good Governance. Bandung: Yayasan Obor Indonesia.

Kazim, Azhar, dkk. 2015. Merekonstruksi Indonesia : Sebuah Perjalanan Menuju Dynamic Governance. Jakarta : PT. Kompas Media Nusantara

Kusuma, Bagas H. 2013. Ketersediaan Ruang Terbuka Hijau Sebagai Penopang Kawasan Mixed Use Pada
Koridor Jalan Fatmawati Semarang. Jurnal Teknik PWK Volume 2 No. 1. Semarang : Universitas Diponegoro.

Maruddani, dkk. 2010. Pemanfaatan Ruang Terbuka Hijau Sebagai Ruang Publik Di Makassar (Kasus : Lapangan Karebosi,Lapangan

Hasanuddin,Taman

Macan,Taman Hasanuddin, Lapangan Andi Matalatta). Lembaga Penelitian Dan Pengabdian Masyarakat (LP2M) Makassar

Universitas Hasanuddin.

Miles, M dan Huberman, A.M. 2007. Analisis Data Kualitatif: Buku Sumber Tentang MetodeMetode Baru. Jakarta: Universitas Indonesia Press.

Moleong, Lexy J. 2012. Metodologi Penelitian Kualitatif. Bandung: Remaja Rosdakarya.

Pohan, Chairil Anwar. 2014. Perspektif Kepatuhan Pajak Dalam Upaya Pemberantasan Korupsi. Prosiding Seminar STIAMI Volume I, No. 02, Oktober 2014.

Rijal, Syamsu. 2008. Kebutuhan Ruang Terbuka Hijau Di Kota Makassar Tahun 2017. Jurnal Hutan dan Masyarakat, Vol.3, No.1. Dosen Fakultas Kehutanan. Makassar : Universitas Hasanuddin

Sedarmayanti, 2009. Manajemen Sumber Daya Manusia Reformasi Birokrasi dan Manajemen Pegawai Negeri Sipil. Bandung: Rafika Aditama 
Sugiyono. 2011. Metode Penelitian

Kuantitatif, Kualitatif dan $R \& D$. Bandung: Alfabeta.

Surjadi. 2012. Pengembangan Kinerja Organisasi Publik. Refika Aditama. Bandung.

Tahir, Arifin. 2011. Kebijakan Publik dan Transparasi

Penyelengaraan Pemerintah Daerah. Jakarta : PT. Pustaka Indonesia Press

Teguh, Ambar. 2011. Memahami Good Governance Dalam Perspektif Sumber Daya Manusia. Yogyakarta : Gava Media

Widodo, Joko. 2008. Good Governance : Telaah Dan Dimensi Akuntabilitas Birokrasi Pada Era Desentralisasi Dan Otonomi Daerah. Surabaya : Instan Cendikia.

Direktorat Jenderal Penataan Ruang Departemen Pekerjaan Umum. 2006. Modul Tata Cara Penyusunan Peraturan Zonasi, Jakarta : Departemen Pekerjaan Umum.

Peraturan Menteri Dalam Negeri Republik Indonesia Nomor 1 Tahun 2007 Tentang Penataan Ruang Terbuka Hijau Kawasan Perkotaan. Jakarta.

Peraturan Daerah Kota Makassar Nomor 6 Tahun 2006 Tentang Rencana Tata Ruang Wilayah Kota Makassar 